\title{
BETWEEN THE MIDDLE AGES AND THE MODERN AGE, THE ITALIAN CONTRIBUTION TO EUROPEAN REFLECTION ON EPIDEMICS: DID JURISTS ADVISE GOVERNMENTS?
}

\author{
TRA MEDIOEVO ED ETÀ MODERNA, IL CONTRIBUTO ITALIANO \\ ALLA RIFLESSIONE EUROPEA SULLE EPIDEMIE: \\ I GIURISTI CONSIGLIARONO I GOVERNI?*
}

\author{
Mario Ascheri \\ Istituto Storico per il Medioevo di Roma \\ Universities of Sassari, Siena, Roma 3
}

\begin{abstract}
English: This work aims to present what some Italian jurists at the beginning of 16th century, during a new series of epidemics, thought useful to prevent and preserve from epidemics. Their tracts, in Latin language, were widespread all over Europe since they summarized the experience of many centuries. Their advices were given governments to show how many possibilities were open to deliberate according to the European common law and therefore they are useful tools to judge the enacted local provisions.
\end{abstract}

Keywords: Middle Ages; Modern Age; epidemics; Italian jurists

Abstract Italiano: Proposito di questo contributo è presentare il lavoro svolto da alcuni giuristi italiani a inizio del secolo XVI, in occasione di una nuova serie epidemica, per contribuire a prevenire e a contenere le epidemie. I loro trattati, in latino, ebbero larga circolazione europea e seppero sintetizzare l'esperienza di tanti secoli. I loro consigli indicavano ai governi le possibilità di intervento che il diritto comune europeo conferiva loro per cui sono utile strumento di valutazione dei provvedimenti adottati localmente.

Parole chiave: medioevo; età moderna; epidemie; giuristi italiani

Table of contents: 1 . Many diverse studies for a single threat. -2 . Italian Predominance: at the time... -3 . Summary of the Legal Opinions -4 . Regulations of Direct Interest to Individuals. -5 . The Treaties on the Remedies Outlined Above. -6 . The Context.

\footnotetext{
* Italian Review of Legal History, 7 (2021), n. 2, pagg. 31-45

* https://riviste.unimi.it/index.php/irlh/index

- ISSN 2464-8914 - DOI 10.54103/2464-8914/16881. Articolo pubblicato sotto Licenza CC-BY.

* The article, published in Italian in "Accademia dei Rozzi", 54, 2021, pp. 82-89 titled Epidemie: antiche proposte italiane per l'Europa (https://www.accademiadeirozzi.it/riviste/), here enlarged, has not been peer reviewed.
} 


\section{Many diverse studies for a single threat}

In 1825 a French doctor who became famous for having faced the epidemic that exploded among the Napoleonic militias in Egypt, Renè-Nicolas Dufriche Desgenettes, published in a professional magazine an essay on a rare treatise on the plague which he boasted of the discovery. He wanted to underline the continuing relevance of the preventive measures: «Presque toutes les dispositions pénales relatives à la peste et indiquées par Ripa, sont fondues dans notre loi sanitaire» ${ }^{1}$.

Almost 300 years after the first publication of that work, his proposals were still noteworthy. And we might ask ourselves who the 'Ripa' he mentioned was. But in the meantime the issue was undermined because of the spread of the no less fearful cholera, as well as the widespread 'Spanish flu' in the early twentieth century. About that, a serious attention has still recently been devoted from a historical point of view with even sensational titles-embarrassing today ${ }^{2}$; these scholars certainly didn't imagine how much this memory would soon become relevant.

We read about the "exile at home» after World War II from the dense pages of Albert Camus, even though the plague had still appeared in Taranto right at the end of the war ${ }^{3}$ and was endemic in areas under the control of the 'Third World'4.

The epidemics had become the subject of history, meanwhile, taking advantage in Italy of the great documentary work published in the nineteenth century by a learned Palermo professor of medicine, with obvious evidence in other countries $^{5}$. Meanwhile, out of necessity, a medical discipline was being developed which/that favored National health legislation ${ }^{6}$ also flourished in hospital history studies, which have increased over the last few decades ${ }^{7}$.

There is no need to talk about - while the media suffocate us with information - the publications on the epidemics of yesterday and today, seen in all the implications that have accumulated in the last year by booksellers; perhaps the only dealers somehow more popular in recent months, to better handle the lockdown

\footnotetext{
${ }^{1}$ Desgenettes, 1826, p. 157.

${ }^{2}$ Among many studies Tognotti, 2015 and Spinney, 2018; extensive examination of the reflections in the literature Outka, 2020.

${ }^{3}$ Leone, 2000.

${ }^{4}$ Standard work as introduction on charge by WHO is Pollizter, 1954, published in English at the same time.

${ }^{5}$ Corradi, 1865. On France, see the example Ozanam, 1817, and for Britain the work by Creighton, 1891-94 continued by Eversley, Ashworth Underwood, Ovenall; in Germany many learned examinations were first regional according to the late political unification. ${ }^{6}$ Cea, 2019.

${ }^{7}$ For example, after his previous important works on hospitals, Henderson, 2019. Studies on the hospital of Santa Maria della Scala have intensified in recent years, in connection with the great project of transforming Sienese art into an acropolis hoped for by Fabio Bargagli Petrucci and Cesare Brandi, after the pioneering conference that gave rise to the volume Spedale of Santa Maria della Scala, Proceedings of the international research conference.
} 
and free time that we would prefer not to have. We have rightly spoken of 'war' to recall an exceptional situation, which requires an extraordinary mobilization: and such a government has finally arrived-unfortunately late, according to many. The time factor in these cases is essential, and the already evident global geopolitical and economic imbalances of our days will end up being greatly aggravated by a very serious epidemic such as the one that is gripping us in this late 2021 .

Nothing will be the same again, I rightly fear, and the emergency could / should be overcome within the year with vaccines, even if the hypothesis of a virus capable of surviving under changing guises is unfortunately faced more and moreoften upsets our wish to control despair. This psychological unconscious attitude of sweeping the emergency under the rug, as it will no longer occur in the future, is so deeply historically rooted that even in contemporary life it can be traced to repeated verifications.

Even today, prosperous states with professional bureaucracies have been caught unprepared. There was a lack of coherent and basically permanent regulations in this regard-necessary well beyond those adopted for serious experiences such as the disastrous earthquakes or the devastation facilitated by climate change or hydrogeological instability.

Unpreparedness is the opposite of 'good governance'. It is one thing to be in the wake of events, another and quite different thing is to try to influence their direction. This is the challenge of the painful current affairs, which has also occurred in the past, also giving rise to a very significant (and unprecedented) reaction to the emergency: the one that occurred at the time of the jurist Ripa referred to in the opening.

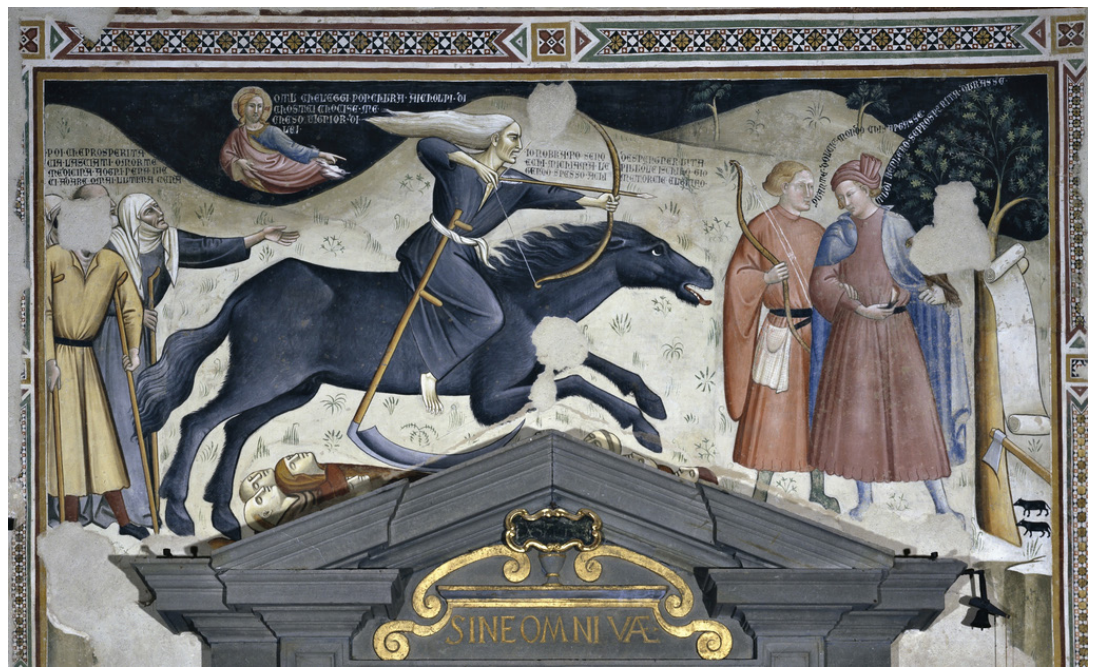

Bartolo di Fredi, TRIonfo della morte, fresco, ChuRch of SAN Francesco (LUCIGNANO). THANKS TO COMUNE DI LUCIGNANO (AR) FOR THE PERMISSION TO THE PUBLICATION OF THE IMAGE 


\section{Italian Predominance: at the time...}

European history has valued our country very differently over the centuries. The last centuries of the Middle Ages and the early Modern Age - from the twelfth to the seventeenth century, from the Romanesque to the Baroque age to be clear - marked a massive presence of Italy in its various articulations: from art to economics, to research and university teaching. For the law it was an important period of leadership that can be considered as a whole, bearing in mind that European universities were governed by similar systems and by very homogeneous teaching.

Italian jurists, in particular, created a unitary law, starting from the legislation of Roman origin partly inherited from canon law, to be applied in the absence of local regulations. They knew that their teaching would reach institutions and political powers, which would certainly then have taken it into account (to a greater or lesser extent) given that their advisers had had a university education. Communication between universities and political power was 'natural' then, because universities knew how to propose solutions to the problems of the time.

Even for epidemics, jurists were able to formulate reflections that, written in university Latin as they were, circulated widely throughout cultured circles up to at least the eighteenth century. ${ }^{8}$ For the time of the epidemics, which was considered the domain of 'necessity', that of the brocardum 'necessitas non habet legem', legal normality clearly had to undergo exceptions. The rigor iuris had to accommodate relaxationes to avoid obvious injustices, as in wartime. Here, we shall only offer a summary of the problems that emerged; we intend to clarify how this culture of normative precepts was elaborated in a future contribution.

\section{Summary of the Legal Opinions}

Epidemics did not arise out of nowhere. That was well understood: jurists learned something from reading the classics, even though they were not subtle philologists like the humanists, and were boring and used to endless legal cases (like today, for that matter) ${ }^{9}$.

Jurists held rulers responsible for general preventive defense, taking into account the possible natural causes of the epidemic, somehow connected to the rationality of the built city. Jurists were also well aware of the complications of inducing rulers to do what 'good governance' required, even though ancient law had provided institutions for this specific purpose, from the defensor civitatis to actiones populares. In fact, jurists obtained abundant normative prescriptions on

\footnotetext{
${ }^{8}$ For more information on the 'remedies' we are discussing, see Ascheri, 2020. Stefano Vinci has already shared his useful comments and integrative notes on the following time period in Vinci, 2020. For previous work on the subject see Ascheri, 1975 (published without notes in Ascheri, 1991, pp. 13-54).

${ }^{9}$ Allow me here to refer to Ascheri, 2015.
} 
public waters, drainage pipes and burials from Roman legal sources (and from excellent treatises such as that of Vitruvius). The city had to be founded on suitable, aerated terrain, with abundant water to use etc.

Needless to say, the 'physical' causes of the epidemics accompanied and worked together with those more rooted in the population, the ones regarding religious explanation. Sin remained an element of individual and collective weakness of the first order in Christian society; therefore, the best prevention for society and the individual against epidemics was life properly lived - in strict compliance with the obligations that everyone should have known thanks to ecclesiastics - who, unfortunately (it was emphasized), were not always up to the task. But on this basis, they wondered which was the best of medicines: which one, if not confession?

Apart from prayers (and for some, unfortunately, even the processions!), public administration of the economy presented itself as fundamental, because our jurists understood the existence of some relationship between the weakness afflicting the community in times of famine, and the spread of the epidemic. Therefore, regulations were needed for subsistence, in particular to support agricultural production, which was fully incentivized by law-even for the use of abandoned lands, res nullius. And in case of shortage, there was no doubt about the validity of the export bans, in order to counteract the current state of emergency. But there was another moment to consider: what to do in that moment from the well-governed society of normal times, to the rise of the first signs of the epidemic?

Prevention had to become more attentive, specific to the rising emergency. The city would immediately protect itself with rigorous control of access, leaving any risk on the outside, but without raising a wall: mercy required that the healthy who fled from a plagued place be welcomed! However, that welcome involved oaths and health certificates (the person must have traveled the direct route without stopping), while the main individual precaution was to ensure isolation from possible infections by obtaining a house in the countryside with an adequate food supply - which was, as is known, a remedy unfortunately not accessible to everyone. Could, however, the welcome of the ruler - the feudal lord of the city for example - who showed up sick at the gates, be denied as it was for normal strangers? The solution was found by reserving an isolated, separate house with adequate food supplies for him.

At the same time, the expulsion of categories considered somehow dangerous became topical: middle-men and pimps had already been excluded from the city, but now prostitutes certainly had to be added to that list (also to control the containment of sin, somehow considered the 'cause' of the epidemic), while the problem of the Jews, always very acute (the years of the trial of Trento for the ritual sacrifice of 'San Simonino' had just passed in the very early 16th century), not yet 'resolved' from the ghettos-also suggested expulsion. There were even 
those who wondered whether it was better to resort to Arab doctors rather than the Jews, enemies and murderers of Christ!

All acute problems when the crisis reached its peak, but the question was not raised whether the local community was superiorem recognoscens or not. If not 'independent', it certainly had to have a placet from the superior to make certain regulations. But even here, we introduce necessitas, which has no law and leads to the saying that the community could still make the necessary regulations and then ask for the placet del superior, since they could not wait for the authorization of the superior to solve certain problems.

For example, the current defense required providing assistance to the sick, first by medical doctors and then, if possible, by private individuals, who should have made themselves available for humanitarian reasons. Therefore, the doctor's remuneration needed to be defined, and it had to be adequate in situations of extraordinary danger. Doctors also helped by intervening in burials, having to attempt to define - not always easy - the order of deaths in a family, taking note of it for their successors. Otherwise it would have been necessary to resort to presumptions in the absence of certification.

Ration payments should have been ensured as a matter of civic duty, but in the event of the escape of the citizens involved, other available people (even convicted ones) had to be hired, as for burials, disinfection, and the closing of homes where epidemic outbreaks had occurred. The essential public service, the hospital, now had to be reinforced for the inhabitants within the walls; while for the infected or suspected strangers who rushed to the city and were not admitted within the walls, assistance was provided in special hospitals - under the formal government of the bishop if he had somehow participated in financing it.

If allowed, there was a treatment that had to be equal, which also implied there was a special treatment for beggars. In medieval doctrine, the presence of the poor made the civitas perfecta, because in its absence the city would not have been complete. The beggar who was able to work was considered a dangerous character, so instead of being in need of care he had to be expelled.

In general, however, the financing of public interventions was experiencing an unusual acceleration. It could still be obtained with forced loans or with extraordinary taxes on assets: it was remembered - with, as can be imagined, understandable fear - that in some circles the dangerous mantra omnia communia tempore necessitatis was current!

\section{Regulations of Direct Interest to Individuals}

In regards to private individuals, it was assumed that the remedies provided could be only invoked when the plague acquired public recognition, because otherwise it had to be considered legally irrelevant. The isolated infected who did not arouse public health fears, could be safely ignored for the purposes of public, if not preventive, action. If, on the other hand, the epidemic became a concrete 
threat, that would trigger a set of legal precautions that were inspired by the relaxatio of the rules of the times of ordinary administration. And that represented a challenge for legal doctrine, because, at the local level, there was not always the foresight and calm reflection that would allow for the drafting and notification of the exceptional rules required by the unforeseen situation.

In case of a lack of explicit rules, it was necessary to face the issue of escape (with iusta causa because the plague was worse than the bellum humanum) and how the status of the people affected what was the normal and recommended practice. The fugitive had to be protected in the places where he took refuge - if he respected the rules imposed by the local authority - but prolonged stay could involve, for example, the birth of a child: will he then be presumed born in the city of origin, or will he acquire the citizenship of the place of refuge?

As for the operators of certain economic and professional activities, to what extent was escaping justified? For the doctor, the answer was obvious, of course, but it was not excluded (I verified this in a contract of employment of 1499 by the Municipality of Montalcino) that the contract itself excludes service in the event of an epidemic! A testimony relating to Florence in 1523 also does not speak much in favor of the doctors' piety: the Christian ones had disappeared, and a Jewish doctor from Pisa had to be hired, says the reliable professor Silvestro Aldobrandini, of the Florentine ruling class, indomitable anti-Medicean, then father of the future Pope Clement VIII.

For ecclesiastics, a duty of presence for religious obligations - which had unfortunately become more burdensome, as well as dangerous-was indispensable from an ethical-religious point of view. It would have been meritorious for the bishop to keep the residency, but it was more common for a vicar to be appointed, while the parish priests had to somehow ensure the extreme services in the areas of their respective competence. The bishop, however, became essential to the question of the contribution he could make to the hospital and to the subsistence of foreigners, or the sick poor. For example, could what was obtained from the income of vacant benefits not be destined, like the other donations received as piae causae, to face the emergency?

The problems which arose from the weakening of public administration were if anything just as substantial. Can the podestà be replaced by his collateral judge and therefore pronounce sentence even outside the appointed place? It was admitted, as the subrogation by the civil judge with respect to the criminal and vice versa: as long as justice did not completely fail, like the police services necessary to force the humblest and outcast functions (burials). It goes without saying, however, that the statute of limitations was suspended, as were, normally, the hearings and the normal formalities for appeals, tests, absentia and so on.

A trace of persistence of the judicial service - suspending voluntary jurisdiction, to be resumed with great care once the contingency has been overcome, for the appointment of the guardians of orphans who were minors, for exam- 
ple - would have been useful to allow the protestationes: in other words, the acknowledgments reported to the authorities that, by doing so, remained to be ascertained with a certain date; the private individual, in some way damaged, had every interest in having harmful facts recorded for him to use (if he can) after the epidemic.

For local public life, still necessary despite the emergency, (wealthy) municipal councilors could be expected to flee, so they could admit their subrogation by their children and the possibility of deliberating with a lower quorum than that required.

The unavailability that could become a consequence of flight also posed legal problems. To what extent could it be assumed that the interested party would be aware of legal acts concerning him, or able to continue to fulfill the obligations imposed on him? The problem could arise even for spouses, with a case that took note of the 'marginality' of women: for example, apart from the lack of sexual obligation, a healthy husband was authorized to abandon his infected wife, as long as he left her with enough to live on.

For the debtors of services, normally required to comply with exact and timely fulfillment, the relaxatio hypotheses in their favor were discussed analytically on the basis of the various mandatory relationships, in particular for the hypothesis of the employment relationship, which was usually suspended, with failure to pay salary due to lack of service. It is no coincidence, however, that the professors configured theirs as a special contract, giving rise to the payment of an honorarium for the type of highly qualified service. The moral was: if the firm suspended the lessons, they still had to be paid, while the runaway student's obligation to pay for his accommodation could be discussed-if the lease had been specific for that purpose, failure to comply with the obligation could be defended. A wise professor, however, around 1500, made provision for the payment of the fee in the contract, regardless of the situation of the courses.

In the ordinary management of leases, at least a partial reduction of rent was postulated, provided that the period of non-use was documented: a jurist recalls, for example, that an exemption was ordered for Rome by Pope Adrian VI, therefore in the plague of 1523.

But emphyteusis already presented different problems, given its long duration and the scarcity of the rule of recognition that would not have justified a relaxatio, except for the normal stay of execution.

Renting and leasing of animals posed delicate problems regarding the risk of deaths in terms of time and place with respect to the conclusion of the contract. In the event of an epidemic, transportation also exempted certain commitments made by the owner, especially in the case of ships, recalling the analogy with the situation of shipwreck already provided for by ancient law. Still on the question of risk-taking, the increasingly frequent case (since the fourteenth century) of entrusting to an external company the collection of indirect taxes, such as taxes 
at the gates of the city on incoming goods, wine, grains, etc. was also discussed. Here, the form of the contract became important because the solution depended on the configuration of the service as a locatio operis, or on the temporary sale of those proceeds given that a certain pretium was collected - but also in view of an ordinary income that was now largely lost. The practice advised companies to proceed with insurance, as documented for Genoa around 1500.

As for the conditional charges that could be imposed on a contractor, the discussion is mainly about the possibility of cancellation, or simply of a postponement without affecting the expectation that was connected to them.

Perhaps the most discussed problems, however, were those that gave rise to more conflict once the emergency was overcome. And, in particular, it concerned the failure to comply with the formalities provided by common law or by local law for acts of alienation that could also be of great importance, such as wills and donations. The place, whether the notary was authorized or not, the assistance of designated relatives, the number of witnesses based on various normative provisions (above all, 9, 7, 2 or was it enough to write in blood as in testamentum militis?) were discussed-recalling among other things the famous case of the wife of a well-known Milanese jurist (Signorolo degli Omodei) who pronounced her will standing at the top of the stairs with a notary and witnesses at a safe distance on the street.

Any special prohibition imposed for the occasion included a penalty, of course. And the problem of anointing, which had not been foreseen, also arose in Bologna: the discussion admitted the death penalty without great hesitation. Moreover, even if not foreseen as a crime defined by edict, it must be remembered that the similar application of the rules before 1700-1800 was absolutely normal in criminal law, so for what was considered a novum crimen a repressive solution, appropriate for the severity and status of the person, was always found.

\section{The Treaties on the Remedies Outlined Above}

Within the enormous literature about the epidemics of yesterday and today seen from every angle-which unfortunately and understandably has become very copious in recent months - the ancient legal aspects mentioned above have not so much been set aside, but have remained unknown for a very simple reason: because it is not imagined, today, that jurists could deal with these problems other than as a result of some specific law, adopted in this or that city.

Normally, studies of the history of epidemics take into account more or less large local situations and illustrate what it is possible to ascertain about the epidemic period from chronicles, legislative measures, notarial deeds, etc. weather. I myself began to deal with these issues by reading a beautiful French book on the plague of 1300 in Orvieto ${ }^{10}$ which functioned somewhat as a model for other

\footnotetext{
${ }^{10}$ I even had the pleasure to review Carpentier, 1962, in Ascheri, 1968. A beautiful antho-
} 
investigations of the same kind-normal nowadays, in an attempt to make an overall revision of the sources to offer a concrete idea of how the city dealt with the problem. We have, of course, a great historical production also for the plague in Milan described by Manzoni, which is very well known, useful instead for the next one that hit Rome hard (fortunately for the last time) ${ }^{11}$.

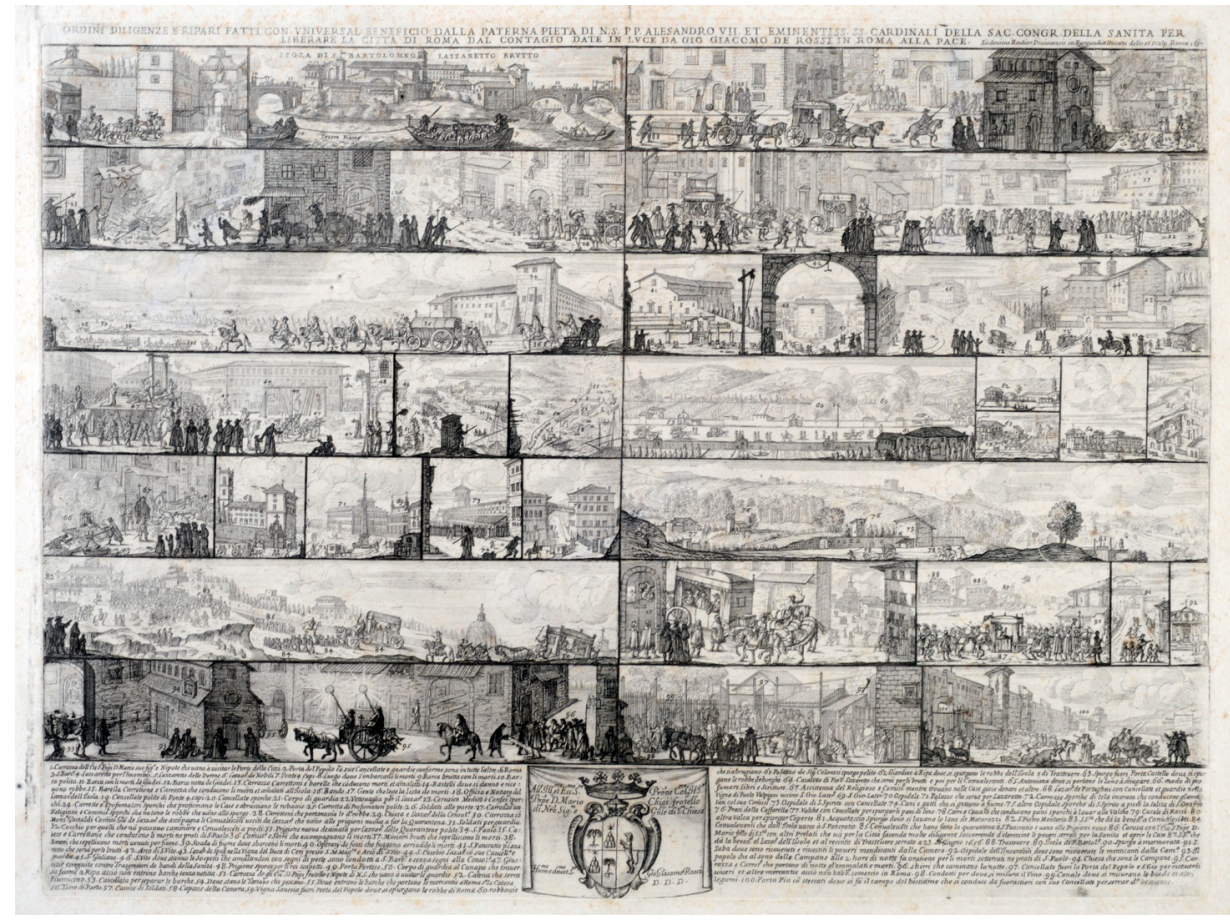

L. ROUHIER, IMMAGINI DI ROMA DURANTE LA PESTE DEL 1657, 1657, ACQUAFORTE, INV. GS103, Coll. Roma, Museo di Roma, GabinetTo delle Stampe (Roma, Museo di Roma, ARCHIVIO ICONOGRAFICO).

Copyright Roma - SOVRINTENDENZA CAPItOLINA AI BeNI CULtURALI - MUSEO di Roma

The problem of a careful reconnaissance at the local level exists because legislation was usually limited in force, also due to the difficulty of having it delivered at a distance, given the urgent need to take action and the widespread terror of the pandemic. There were therefore notices, which were normally made public precisely in the streets with a drum roll, as well as in churches, while the statutes were normative sources, usually used for ordinary administration, made available to the public and therefore known by everyone.

One of the problems discussed in the legal doctrine was precisely that of the possibility of assuming ignorance of local law. The answer was generally negative

logy of short, but meaningful stories, in Bowsky (ed.), 1971.

${ }^{11}$ I recommend the excellent book Fosi (ed.), 2006. 
even for the stranger who, by going to another city, had to have the diligence to inquire about the local regulations. It is clear, however, that in times of epidemic this rule also had to find a relaxatio, as they called it. It should be borne in mind that the cities of the declining Middle Ages were the result of very organized societies, usually also organized in making laws known (for businessmen, for example, by publishing them in the Merchant's Guild).

In sum, the legal problems of epidemics were certainly faced by medieval jurists. In the fourteenth-fifteenth centuries there had been important medical consilia on the plague, obviously extensively studied, which had taken on the breadth of real treatment of the various aspects of the epidemic problem (plague or sometimes cholera, for example) ${ }^{12}$. The jurists ${ }^{13}$, however, had not organically responded in regard to the epidemics, which is why, for example, we have a Tractatus de bello dedicated to the issues raised by war already by the end of 1300 , and one of the argomenta by analogy that will be used will be precisely that of de bello ad pestem, to bring epidemic situations under the exceptional regulations foreseen for wartime.

In the fourteenth and fifteenth centuries, however, so much casuistry was dealt with in the dense commentaria intended for teaching, or in specific consilia dedicated to specific causes, without however collecting the rich juridical casuistry in the form of the tractatus, the one that traditionally allowed (as early as 1100) attention to be drawn to a theme regardless of the forms of teaching typical of universities.

Between 1522 and 1524, instead, two treatises were published, while a third remained in the form of a manuscript ${ }^{14}$ : that is, probably because the author, Silvestro Aldobrandini, a very young reader of Institutions in Pisa, became aware of the first Tractatus del Ripa published already twice by 1522 .

The author was Gianfrancesco Sannazari della Ripa, a Lombard jurist of some importance (also over forty at the time), called to teach in Avignon from 1518 and, having become well known, then awarded the office of senator in Milan, that is member of the most important judicial body of the duchy. In short, he was a contemporary a little older than Andrea Alciato, the great humanist jurist, who followed part of his career between Avignon and Milan, acquiring extraordinary fame. Ripa, on the other hand, was a master of mos Italicus by definition and as such he was called to Avignon: that is, to teach how it was done in Italy, because

\footnotetext{
${ }^{12}$ Italian jurists today have a great introductory and specific tool, the Dizionario biografico dei giuristi italiani (XII-XX secolo), diretto da I. Birocchi, E. Cortese, A. Mattone, M.N. Miletti, I-II, Bologna, il Mulino, 2013.

${ }^{13}$ Bartolus good example: see Mari, 2020.

${ }^{14}$ I did not think it was necessary to publish the inedited part of his treatise, which is now preserved at the Vatican Library, because it basically consists of a collection of private law quaestiones, which are already well present among the two published essays and which he had probably already been discussing together with his students.
} 
right then awareness was developing that another mos was spreading in France and that was thanks to Alciato! Two Italians were models of the two different ways of accessing the traditional legal sources used in all European universities of the time....

Ripa's treatise De peste libri tres, printed in a first edition in Avignon and in a second in Lyon at the end of 1522 (illegally, in response to a clearly high market demand), is the one that has been most successful: 17 editions up to the early 1600 s, and then remembered by subsequent jurists, even if in 1700 the legal problem of the epidemic began to be framed in a different way, because the university sources were giving precedence to territorial legislation, by now written in the local language. But certain publicist cautions could still be taken into consideration. Ripa therefore continued its diffusion, because he tried to point out the broader possibilities that European law gave to all its readers, and partly because it was certainly appreciated by Protestant readers thanks to his polemics against ecclesiastics who were not careful in fulfilling their religious duties.

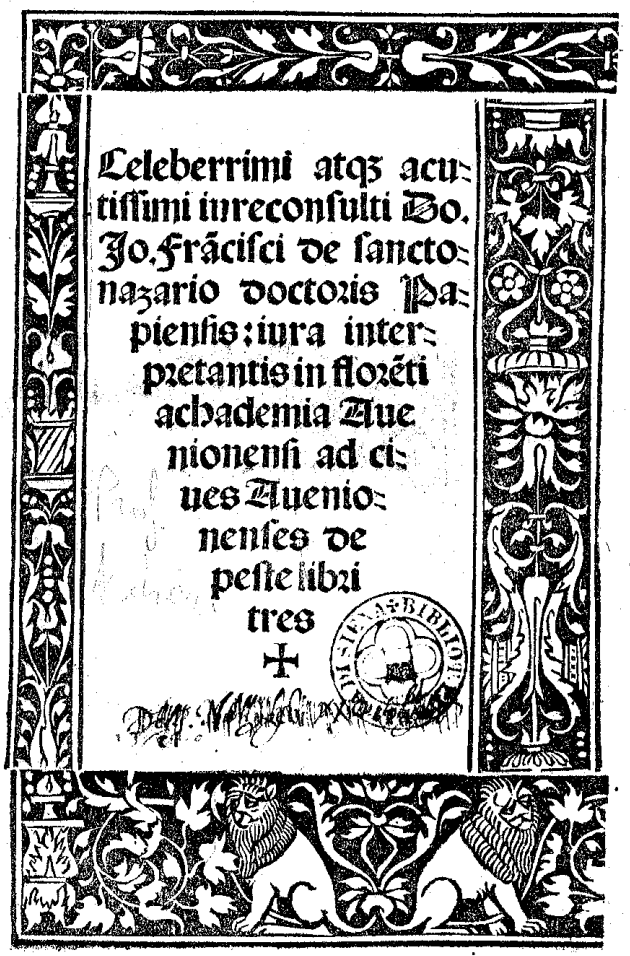

Giovanni francesco Sannazari della Ripa, Tractatus de Peste, Avignon 1522.

THANKS TO BIBLIOTECA COMUNALE DEGLI INTRONATI DI SIENA FOR THE PERMISSION TO THE PUBLICATION OF THE IMAGE 
The third treatise, published in Bologna in 1524, is by a little-known Bolognese jurist, Girolamo Previtelli, and is less organic and complete than Ripa's. Therefore, it was republished only once, in the famous collection of the Tractatus universi iuris of 1584, published under papal auspices, in place of Ripa's richer but more controversial work.

\section{The Context}

Why were the three treatises published exactly at that time? These are events in which it would be difficult to look for a single causal element. There were several circumstances that contributed to that coincidence. We were in a really difficult time. The problems of morality became more accentuated at the end of the 15th century and there was more and more talk of sins, from sodomy to blasphemy, to unbridled luxury, which led to divine revenge and motivated harsher legislation than in the past in criminal law.

The important wars for Italy - from the last years of the 1400s, at least until 1515 , as well as the epidemics and famines - exacerbated the pessimism, but also the hope in a profound renewal of the Church to remedy the unfortunate politics of the popes. These are the years in which, for example, a Franciscan returning from the East remembered «much more honest Turkish women than ours», praising femininity and modesty. The plague finally appeared in $1522^{15}$ in Piedmont and Sicily, and then also elsewhere. In the meantime, from the end of the 15th century, the critique of law and traditional jurists - first an episodic fact, starting from Petrarch - had been strongly consolidated: these are the so-called 'beginnings' of juridical humanism, which would then progress at lightning speed in France and Holland ${ }^{16}$. With these treatises the jurists wanted to mark a presence: to show that they were not only present, but always useful for the good cause of institutions, despite the many current criticisms. ${ }^{17}$

To conclude on the context, we can reflect on the dual usefulness of these texts: first, they allow historians to compare the regulations taken locally in the past with what was juridical possible; second, to evaluate how legal instruments are today more adequate to tackle current emergencies.

\footnotetext{
${ }^{15}$ As well as already being a professor at Bologna, he was the lawyer for the most popular case of his times, Enrico VIII's matrimonial lawsuit. He did not become particulalry famous, though, because he became victim of a plaintiff while going to court, and was then murdereed. Therefore his career was tragically destroyed.

${ }^{16}$ For a more comprehensive review, see Ascheri, 2006. The recent more specific work has not, unfortunately, dealt with the many issues opened in previous works. See Ascheri, 2005.

${ }^{17}$ See my brief, but I believe significant, introduction to Ascheri, 2015, already quoted above.
} 


\section{Bibliography}

Ascheri M., 1968: recensione a E. Carpentier, Une ville devant la peste: Orvieto et la peste noire de 1348, in "Studi Senesi", 80, pp. 253-258

Ascheri M., 1975: Note per la storia dello stato di necessità, in "Studi Senesi", 87, pp. 7-94

Ascheri M., 1991: Diritto medievale e moderno, Rimini, Maggioli

Ascheri M., 2005: Il paradiso perduto dei giuristi?, in "Rechtsgeschichte" 6, pp. 196-199

Ascheri M., 2006: I giuristi: categoria professionale e presenza culturale, in F. Cengarle (ed.), L'Italia alla fine del Medioevo: i caratteri originali nel quadro europeo, II (Collana di studi e ricerche, 10), Firenze University Press, 2006 (actually 2007), pp. 87-110

Ascheri M., 2015: La 'percezione' dell'avvocatura in Italia dal Medioevo all'Età moderna, in "Initium" 20, pp. 689-704

Ascheri M., 2020: Rimedi contro le epidemie. I consigli di diritto europeo dei giuristi (secoli XIV-XVI), Roma, Aracne

Bowsky W.M. (ed.), 1971: The Black Death. A Turning Point in History?, New York, Holt-Rinehart and Winston

Carpentier E., 1962: Une ville devant la peste: Orvieto et la peste noire de 1348, Paris, SEVPEN

Cea R., 2019: Il governo della salute nell'Italia liberale. Stato igiene e politiche sanitarie, Milano, Angeli

Corradi A., 1865: Annali delle epidemie occorse in Italia dalle prime memorie fino al 1850, 9 vols., Bologna, tip. Gamberini e Parmeggiani

Creighton Ch., 1891-94: A History of Epidemics in Britain from AD 644 to the Present Time, 2 vols., Cambridge, Cambridge University Press

Creighton, Ch., 1965: A history of epidemics in Britain, with additional material by D.E.C. Eversley, E. Ashworth Underwood, L. Ovenall, London, Frank Cass

Desgenette R.-N.D., 1826: Notice sur un livrè fort rare de Saint-Nazaire de Ripa, publié en 1522, sur la peste, in "Journal complémentaire du Dictionaire des Sciences médicales", tome 25, Paris, pp. 149-157

Dizionario biografico dei giuristi italiani (XII-XX secolo), diretto da I. Birocchi, E. Cortese, A. Mattone, M.N. Miletti, I-II, Bologna, il Mulino, 2013

Fosi I. (ed.), 2006: La peste a Roma (1656-1657), in special issue of the "Roma moderna e contemporanea. Rivista interdisciplinare di storia”, 14, n.1-3

Henderson J., 2019: Florence Under Siege: Surviving Plague in an Early Modern City, New Haven, London, Yale University press

Leone A., 2000: Taranto fra guerra e dopoguerra: il minamento della rada di Mar 
Grande (1943) e l'episodio epidemico di peste bubbonica (1945), in "Cenacolo" n. s. 12 (24), pp. $149-188$

Mari P., 2020: Il libro di Bartolo. Aspetti della vita quotidiana nelle opere "bartoliane", Spoleto, Centro italiano di studi sull'alto Medioevo

Outka E., 2020: Viral Modernism. The Influenza Pandemic and Interwar Literature, New York, Columbia University Press

Ozanam J.A.F., 1817: Histoire medicale generale et particuliere des maladies epidemiques, contagieuse et epizootiques qui ont regne en Europe depuis les temps les plus recules et notamment depuis le XIV siecle jusqu'a nos jours, Paris, Lyon

Pollizter R., 1954: La peste, Genève, Organisation mondiale de la santé

(Lo) Spedale di Santa Maria della Scala in Siena. Atti del Convegno internazionale di studi (Siena) 20, 21, 22 novembre 1986, ed. C. Infantino, E. Toti, Pisa, 1988

Spinney L., 2018: 1918. L'influenza spagnola. La pandemia che cambiò il mondo, Venezia, Marsilio

Tognotti E., 2015: La "spagnola" in Italia. Storia dell'influenza che fece temere la fine del mondo (1918-1919), Milano, Angeli

Vinci S., 2020: Diritto ed epidemie nell'esperienza giuridica moderna e contemporanea, in "Mediterranea. Ricerche storiche", 17/49, pp. 517-525 